\title{
Beyond the police: libraries as locations of carceral care
}

\author{
Teresa Helena Moreno \\ University Library, University of Illinois at Chicago, Chicago, Illinois, USA
}

\begin{abstract}
Purpose - The purpose of this paper is to make visible the connections libraries have to carceral systems and how library workers replicate carceral behavior through care.

Design/methodology/approach - This paper uses interdisciplinary research methods in the fields of library science, criminology, feminist studies, Black studies and abolition to examine the role of libraries as locations of carceral care.

Findings - Libraries, through their history and funding as well as their roles within society as educators and social service providers, have the components necessary to act out carceral care; libraries by extension can and do participate in forms of carceral care.

Originality/value - There has been much work on carceral care in the fields of social work and education, but to date, there has been little to no scholarship on how libraries work within the landscape of carceral care. This article builds upon the work of others to help understand how it applies to libraries.
\end{abstract}

Keywords Libraries, Ethnic minorities, Culture, Librarianship, Feminism, History

Paper type Conceptual paper

\section{Introduction}

In late spring 2020, a critical moment was reached in movements for Black lives. The murder of George Floyd by police spurred a series of uprisings as a response to centurieslong forms of state-sanctioned violence and murder of Black, Indigenous and people of color (BIPOC). The engagement of the people of the USA was vast, with participation in all 50 states and with 500 actions taking place nationally (Bourne, 2020). With so much involvement by the American people in the uprisings of spring and summer 2020, we began to see a national discourse around police, the concept of policing, reform, and police and prison abolition. As this discourse entered our collective conversations nationally, many institutions began taking part in these conversations, considering what reform or abolition could mean for their institutions and what it could mean to challenge the notion of a policed society. Libraries entered the conversation and sought to reflect on their relationships with the police and police structures. Collectives of library workers working toward abolition such as the Abolitionist Library Association created space for education, discourse and action (Abolitionist Library Association, 2021). On June 11, 2020, the American Library Association (ALA) released a statement condemning violence against BIPOC, protestors and journalists. In this statement, the ALA called upon its members to "support initiatives to end police violence against Black people, to combat the systemic racism that infects our society, and to speak out against all attempts to restrict first amendment rights" (American Library Association, 2020). As a result, library workers and libraries started to evaluate their ties to police and security guards.

Op-ed pieces illuminated the ways in which library workers may need to reconsider their reliance on police as it can endanger the lives of Black and other minoritized populations (Dapier and Knox, 2020). To that end, the Los Angeles Public Library investigated how much money the library was investing in the Los Angeles Police Department, and administrators were shocked to discover that the security budget had increased to $5 \%$ of the total library's budget; the Denver Public Library had also allocated $5 \%$ of its budget to local police, with the Austin Public Library not far behind at $3.2 \%$. The movement to eliminate police presence in libraries continued in cities

Received 12 July 2021 Revised 18 September 2021 9 November 2021 17 November 2021 Accepted 18 November 2021 
like St. Louis and New York where organizers pressured communities to divest from police and contracts with local security and private companies (Fassler and Ventura, 2021).

Recognizing the problematic nature of police and security presence within libraries, library workers striving for more inclusive practices have landed on a range of possibilities to address the issue. Some libraries have moved toward police and security wearing plain clothes and being unarmed. Others have articulated how the funding structures for police could be reallocated, making requests for the integration of social workers and other professionals within the library to address the needs without police (Balazer, 2020). In the wide array of responses and reimagining of police in the library, the focus of these measures is mostly on police and security presence, but less on policing infrastructure-that is, the ways in which the policing and criminalization of minoritized communities can occur through everyday practices, infrastructures and policies, regardless of physical police presence. For many individuals who are rethinking their relationship with police, the main goal is to prevent murder, violence, and criminalization of minoritized communities. Physical police presence is not a necessary requirement to engage in policing behaviors that can lead to violence against minoritized communities, and many scholars, activists and community organizers have worked to outline how the absence of police does not necessarily lead to the absence of policing. For library workers who are committed to removing policing in their libraries, what is required is an examination of how libraries and their workers engage in acts of policing and carcerality themselves.

This paper is built upon the criminologist concept of police, policing and the landscape of policing. Scholars of policing encourage us to think of policing as an umbrella term that encapsulates a wide variety of actions that are utilized to create and maintain a defined idea or notion of social order; moreover, scholars assert that such actions can be performed not only by state agencies and professional police but also civilians and workers outside of the police profession. In short, it is the idea that policing can be performed by anyone and at a number of societal locations (Reiner, 2010). To examine the covert ways policing infrastructure is woven into the structure of libraries, this paper will explore the concept of carceral care to demystify how libraries participate in carcerality that is further complicated by libraries' roots in education and social services as well as how the impact of social service funding structures and neoliberalism have created situations conducive to forms of carceral care. In the examination of carceral care's place in education and social services, this paper will also use those frameworks to provide both historical and contemporary analyses of librarianship and locations of carceral care within the field.

The presence of police officers in libraries is worthy of examination; however, this paper is centered on what library workers and systems do that can be seen through the lens of the concept of carceral care and not what police themselves do in libraries. It should also be noted that the examination of the aforementioned is predicated upon the knowledge of the ways in which policing and the prison nation disproportionately impact BIPOC, with additional opportunities for criminalization as race and ethnicity intersect with gender, sexuality, disability and more (Davis, 2003; Alexander, 2020; Richie, 2012; Schenwar and Law, 2021). As such, while it is beyond the scope of this paper to provide an in-depth introduction to abolitionist principles, scholarship and discourse, this paper employs these concepts through drawing upon scholars who critique prison systems and in some cases call for an abolitionist approach to prison systems.

\section{Defining and understanding carceral care}

To begin to understand how it is that libraries and their workers can enact carceral care practices, we must take a moment to define carceral care and place it within institutional contexts. In the context of this paper, care is defined as programs and social services intended to 
equitably benefit the community, such as education and after-school programs, health care (including mental health care), and other related services, including library services. The term carceral in this paper moves beyond literal forms of incarceration, instead referring to societal action that "shapes and organizes society and culture through policies and logics of control, surveillance, criminalization, and unfreedom" (Tapia, 2020). Combined, in the most simplistic sense, we can think of carceral care as work that centers community-oriented caregiving but relies on carceral frameworks and power structures to produce such care. Theorists such as Michel Foucault have long described the ways in which our society relies on surveillance and discipline, thus establishing a carceral culture. In Foucault's Discipline and Punish, he draws our attention to professions of care (e.g. teaching and medicine) as primary sites for carceral culture in action (Foucault, 1995). Foucault is joined in this longstanding discourse by scholarly voices in social work, education, criminology, feminist studies and Black studies as well.

Many scholars enumerate several specific conditions that assist in embedding carceral culture in social services and by extension societal care work. Central to the development of the phenomenon of carceral care is the emergence of neoliberalism-specifically, the funding for and restructuring of public services and nonprofit organizations. In the 1960s, in the USA, we began to see a societal trend in which arms of the state that are typically tasked with care-related social services began to shift the responsibilities of these programs to privately operated nonprofit organizations (Trudeau, 2008). This trend seemed to provide some relief to state budgets while being touted as a means for local communities to identify their own needs and serve their own people. In order to maintain their nonprofit status and receive various forms of funding, nonprofit organizations in particular are required to meet various eligibility requirements that are controlled by individual state laws, thus enabling the state to indirectly engage with various social services and locations of care. Jennifer Wolch coined the term shadow state to describe this phenomenon, which refers to the state's oversight and control of various forms of social services and locations of care without direct participation in care delivery that is instead delegated to nonprofit organizations and other volunteer agencies (Wolch, 1990). In addition to the nonprofit sector, the shadow state is also aided by neoliberal policies and the privatization of the state's work that is relegated to for-profit industry; these conditions contribute to a cycle of defunding necessary locations of societal care and then relying heavily on private and neoliberal models to support these needs, thus destabilizing infrastructure and forcing nonprofit organizations and other care providers to rely on ever-dwindling funding with more and more conditions attached to that funding.

One example of carceral care in action is described in Nicole Nguyen's study of Countering Violent Extremism programs, in which care workers and community leaders, primarily in masjids and Islamic charities, accepted much-needed funds from the US Department of Homeland Security in exchange for surveillance and helping criminalize these care workers' communities (Nguyen, 2021). Nguyen's study is just one example of how the state benefits from defunding various locations of societal care, placing nonprofit organizations in the role of caretaker and maintaining control in order to implement its own policing and criminalization strategies. There are numerous other examples of how this can be implemented. For example, on May 27, 2021, Chicago Mayor Lori Lightfoot announced that the first new Boys and Girls Club location in Chicago since 1995 will be built on the campus of a controversial police training facility in a predominantly Black neighborhood; the new building will be paid for with funds from private donors while the city is permitting the club to lease the land for $\$ 1$ annually. Community reactions to this controversial development reveal tensions between accepting needed community resources and including an increased police presence in an already over-policed community (Sabino, 2021).

In both Nguyen's study and the Boys and Girls Club scenario, a unifying trend emerges, namely the rebranding of police and policing behavior to communities as friendly community 
collaborators instead of punitive panoptic forces. This is particularly salient in prevention narratives, such as "catching" a young person before they join a gang and preventing extremist behaviors. The cost of using these methods to prevent violence, though, is often the criminalization of communities (Lawson, 2007; Schenwar and Law, 2021; Nguyen, 2021). This narrative is further complicated by the direct or indirect involvement of the state, which has historically minoritized and criminalized Black and brown communities in particular (Davis, 2003; Alexander, 2020).

\section{Libraries as educators, social service providers and locations of care}

What we do know about common locations of carceral care is that they are often found in a range of social services, particularly education. Education is a formidable part of the social services landscape, and it is for this reason that we will be discussing education and other social services (i.e. housing, health care, etc.) as locations of carceral care work in this article.

Libraries as institutions have a unique placement within the care landscape because they are involved in education, as well as social services that incorporate other forms of care. In its research statements on the impact of libraries, the American Library Association devotes sections to "social impact" as well as "educational/literacy impact." In these sections, the ALA underscores how libraries are vital to "building strong and vibrant communities" and to the "development of community identity" as well as how libraries are deemed an "essential component of the educational system" as educational institutions that improve reading and literacy skills (American Library Association, no date a). While the educational component of libraries may be taken for granted, libraries have increasingly developed more sophisticated social service offerings as they have expanded their outreach beyond the elite; libraries today offer a place for library visitors to hold meetings, for the commuter college student to study in between classes, for the unhoused to find temporary respite, for community organizations to host programs and for community members to get help with a wide range of needs, from access to the Internet to assistance with filling out job applications (Wahler et al., 2020). Library scholars and library workers have noted these changes, and the shift is present in conference and scholarship discourse. In fact, the shift for libraries to take on these social services has become so formidable that a 2014 editor's letter in The Library Quarterly explicitly states that the journal will specifically consider libraries as "community institutions addressing problems in society" (Jaeger et al., 2014, p. 492). We see this also reflected based on the number of libraries that were considered essential services during the COVID-19 pandemic because of the wide array of social services they provide (Shoenberger, 2020).

The slow job creep of social services work to the field of librarianship over the span of time is one that makes a lot of sense within the neoliberal landscape; the defunding of societal infrastructures inevitably places additional demands on other social institutions (Ettarh, 2018). The movement to restructure funding of public services in the 1960s, 1970s and 1980s has shifted the expectations of what libraries should provide. In an interview discussing the additional social services burden being placed on libraries, one social worker commented, "Due to cuts in funding for social programs, criminalization of drug use, and rising costs in housing, libraries are often the last place people can go" (Freudenberger, 2019). These new expectations created tension in libraries in terms of how best to serve these needs with limited resources. Library scholars and workers have touted the benefits of including social workers in libraries to meet these needs, and social workers have also identified such a partnership as a useful tool for social services care delivery, with both professions identifying libraries as a location of societal care, beyond their educational mission (Wahler et al., 2020; Freudenberger, 2019). 


\section{Carceral care in education and social services}

The intricacies of governmental funding systems and their relative opacity obfuscate when carceral care work is being conducted, but scholars in social service fields have begun to map the practices that create carcerality and criminalization of people within their care. The school-to-prison nexus is a notable articulation of carceral care in the field of education.

The school-to-prison nexus is a lens that lays out the ways in which schools engage in disciplinary policies that criminalize their students and set them on a pathway to incarceration. For education scholar Erica Meiners, the concept of the school-to-prison nexus "aims to highlight a complex network of relations that naturalize the movement of youth of color from our schools and communities into under- or unemployment and permanent detention" (Meiners, 2011, p. 550). Scholars argue that school reliance on a series of extreme disciplinary actions and zero-tolerance policies working in conjunction with the destabilization of other social locations of care creates a direct line for youth to end up incarcerated (Heitzeg, 2009; Rodríguez, 2010; Skiba et al., 2014; Wald and Losen, 2003). Many of the students who find themselves tangled in the web of the school-to-prison nexus also require other forms of social care, including students who are unhoused, underfed, experiencing abuse or struggling with undiagnosed learning disabilities or other health-care needs (American Civil Liberties Union, no date).

Some education scholars have challenged the notion of a school-to-prison nexus by illustrating that schools can function and operate as de facto prisons on their own (Krueger, 2010; Rodríguez, 2010; Stovall, 2018). To support these ideas, scholars point to uniforms, silent lunches, walking demarcated lines and being subjected to random searches (Stovall, 2018). By relying on such practices, schools need not have police officers on their campuses for the policing, criminalization and future incarceration of youth to occur. In this way, education as a social service field has functions of carceral care woven into its very foundation.

Social work as a field within the USA articulates a mission driven by human rights and social justice, having initially appeared in the 19th century in settlement houses (International Federation of Social Workers, 2014). Early settlement houses offered a range of social services such as literacy education and childcare services. Notable social reformer and founder of the prominent Hull House in Chicago, Jane Addams led efforts that produced legislative accomplishments such as the first juvenile court in the USA, the first federal child labor law in 1916 and an Illinois state law passed in 1919 to protect women and children (Jane Addams Hull-House Museum, no date). These legislative efforts, combined with collaborations with the legal system, established social work as a distinct field that continues to rely heavily on its foundation of legal and policing structures. By the 1960s, within the USA, social workers represented almost half of all probation and parole officers (Goble, 2021). In the contemporary moment, scholars and practitioners use the term "police social work" to articulate the ways in which social workers are part of the criminal system itself as they often work in tandem with police on "social" matters (Jacobs et al., 2020).

Through the field's partnership with the legal system, scholars cite social work as a location of carceral expansion into our social systems, including a wide variety of locations of social care (Richie and Martensen, 2020). Abolitionist feminist scholars developed the term carceral feminisms to explain this phenomenon in the context of gender-based violence; specifically, the term refers to an approach that requires a reliance on prisons and legal maneuvers with the goal of protecting people from criminal acts (Kim, 2018). A key critique from abolitionist feminist scholars of carceral feminisms is that the legal system cannot provide justice because in its current formation it is ill-equipped to address the ways in which interlocking systems of oppression greatly impact carceral outcomes (Whalley and Hackett, 2017). Simply put, a reliance on the justice system for justice often can lead to the criminalization of BIPOC individuals as seen in the cases of Marissa Alexander and Bresha Meadows in which both were caught in a prison system for self-defense measures in domestic
Libraries as locations of carceral care 
violence circumstances (Dahl, 2012; O'Hara, 2017). Evidence for this critique is the criminalization of different groups of people at vastly different rates, reflecting the ways in which the legal system maintains social control over minoritized populations (Davis, 2003; Alexander, 2020; Richie and Martensen, 2020). At its core, the term carceral feminisms illustrates that efforts to provide social services can and do add to the criminalization and destabilization of the very communities and populations that the services are intended to aid.

Examining education and social work as locations for carceral care, we see a common thread that links them together-the neoliberal structure of society and subsequent defunding of social services - which has a direct impact on creating what many abolitionist scholars refer to as a prison nation. The movement to rely on forms of care because of the destabilization by the state is transmuted into a reliance on surveillance control and punishment for access to care through the hands of the state. Furthermore, it is in these locations of care that the foundation of white supremacy breaks through to continue patterns of institutionalized forms of racism (Davis, 2003; Alexander, 2020).

\section{Libraries as locations of carceral care}

As institutions comprising both educational and social service forms of care, it follows that libraries are capable of and do produce their own forms of carceral care. Nguyen defines three areas of carceral care work that we can use as a framework for this exploration:

(1) The mobilization of "care work" to fortify carceral power.

(2) The making of care contingent on participation or subjection to community policing.

(3) The activation of liberal narratives that frame these practices as a way to reduce the reliance on law enforcement and increase access to services (Nguyen, 2021, p. 3).

This framework aids in identifying numerous examples of carceral care that affect all types of libraries, including public, school and academic libraries, in all geographical locations serving all types of populations. Loosely applied to libraries, carceral care work may appear as (1) the inclusion of formal carceral systems, such as police in libraries (Nguyen's first area of carceral care work); (2) rampant community policing, such as enforcing standards of citizenship through assimilation practices (Nguyen's second area) and (3) the reframing of such work as prevention, such as gang prevention or job application assistance (Nguyen's third area), thus obscuring the role of carcerality while simultaneously reinforcing it.

To start understanding carceral care in libraries, we must understand the formation of libraries as social institutions as well as the evolution of their funding structures in the USA. In his work on public libraries and the War on Poverty, library historian Jeff Wheeler provides a helpful timeline. In the late 19th century, free and public libraries were established and funded predominantly through private philanthropy by elites as alternatives to carceral systems and as a means to transform the poor into good citizens. This trend continued until the Great Depression, at which point the federal government began investing in library infrastructure, in the short term as a poverty reduction measure but also continuing the elites' goals of producing good citizens. Through the Johnson administration in the 1960s, libraries became more heavily entrenched in the American social services infrastructure, continually expanding the types of services rendered, particularly in urban areas with poor populations but also throughout the country generally. Once neoliberal politics took center stage in the late 1960s and early 1970s, federal funding was greatly reduced, thus requiring libraries to continue to provide many of the same social services but now also forcing them back to relying on significant private philanthropic investments (Wheeler, 2021). For academic libraries, federal funding became consistent under the Higher Education Act of 1965, with all academic libraries becoming eligible for federal assistance — not just the elite ivy institutions (Jones, 1989). 
Acknowledging this history, carcerality has been a constant component of libraries since the late 19th century, with philanthropists specifically seeking to produce good citizens by replacing other carceral systems (such as incarceration and the legal system) with a new alternative, making libraries play the role of prevention programs, relating to Nguyen's third area of carceral care work. The formation of carceral care is established as a core tacit component of libraries' missions and execution of services in history. With the introduction of federal funding, carceral care is formalized with new strings attached to such funding contingent upon their success as defined by federal agencies rather than by the communities they serve. In the neoliberal era from the late 1960s onward, libraries' reliance on private philanthropy provides a multitude of new opportunities for carceral care expansion through a vast web of conditions and requirements outside of the realm of the state for continued access to funding. With this, coupled with the movement in the USA to privatize prisons, we begin to see a symbiotic relationship emerge.

It is beyond the scope of this paper to enumerate all the ways in which carceral care is acted out in libraries. The goal, however, is to demonstrate how carceral care in libraries currently works so that we can employ this critical lens in our own work and institutional forms of care. The following examples are articulated to make this phenomenon more tangible.

One near-universal example of carceral care in action in libraries is the use of a system based on fines. By checking out a book, there is a collective understanding that to access library materials, the patron is subject to a fining system, relating to Nguyen's second area of carceral care work. Some public libraries send fines to collection agencies. The ALA acknowledges that libraries have contracted with collection agencies for this purpose as a last resort in the absence of sufficient state funding (American Library Association, no date b). In this way, we see a neoliberal model forcing a library's hand at criminalizing its patrons. Collections have the potential to impact credit scores, which can hurt people in a myriad of ways financially (Barnard and McGinty, 2007). Arguably, the people impacted by this do not have the resources to pay these fines, which contributes to a cycle of debt, collection and criminalization, which can have carceral consequences. Such a strict and punitive disciplinary measure also prevents people from returning books that were fined or from returning to the library at all in order to avoid paying fines they simply cannot pay. In 2019, the Chicago Public Library (CPL) was the largest public library to eliminate overdue fines. In the first five months after fines were abolished, CPL doubled its returned overdue books (1,650 per month versus 900 per month before fines were removed) and saw a $7 \%$ increase in readership (Dudek, 2020). Libraries' move to abolishing fines is a step in the right direction to removing some of the carceral systems.

Another carceral location is the partnerships that libraries develop with vendors. Making notable headlines is the research giant and data brokerage firm LexisNexis, which has been heavily critiqued for the ways in which it gathers users' data that it then distributes to US Immigration and Customs Enforcement. An April 2021 article in The Intercept describes the ways in which LexisNexis is heavily used by legal scholars but is also reliant on its relationship with its most lucrative clientele, the risk industry - an industry that identifies people as risk factors for financial and legal institutions. The firm caters to the risk industry's needs by producing an infrastructure that makes it easy to demarcate people with criminal behavior and assist in arrests. Again, neoliberalism is aiding a location of carceral care because the library is relying upon a privatized company and that company's own form of regulations to allow patron access to information (Biddle, 2021).

The example with LexisNexis is not a solitary issue. In Sarah Lamdan's work on librarianship and ICE surveillance, she enumerates the complications of information capitalism: the privatization of information, how deregulation occurs through privatization and how libraries' reliance on these companies for information can be incongruent with our claimed mission of patron privacy (Lamdan, 2019). In this particular example, libraries tether 
themselves to carcerality in two distinct ways. First, libraries essentially require patrons to relinquish data about themselves (through database searches, geographical details and other identifying information) that can be used to criminalize them despite ostensibly receiving access to information as care. Second, as the conversation regarding the defunding and reallocation of police resources continues, libraries often consider how much of their budgets are spent on police or policing presence; yet, by paying fees to companies that will share data in this way with law enforcement, libraries are essentially paying for police presence, albeit without police physically present in a building.

\section{Vocational awe, abolition and the future}

These are two prominent examples, though far from exhaustive. For many in the profession, it is conceivable that libraries are not carceral in nature. That comes from the idea that libraries are the great equalizer or the notion that libraries can maintain a kind of neutrality. What many critical theorists of libraries have said before is that libraries are not inherently neutral, not just in terms of the information we hold but also that as institutions we are a part of the same governmental and commercial institutions that mediate expectations of us and our funding (Lewis, 2008).

Further complicating the visibility of libraries as carceral care sites is the profession's sense of vocational awe. Fobazi Ettarh gives us the concept of vocational awe to describe how library workers have internalized the ways in which libraries are marked as solely good and sacred and beyond reproach (Ettarh, 2018). Considering how libraries are components of social services and education, vocational awe can also extend to these other professions which share many similarities; they are seen as "pink-collar" (i.e. care-oriented) professions, many of them articulate their work as answering a call to serve in various capacities, and fundamentally at their core they are trying to be a helpful arm of a good society, all while being caught up in the same funding structures. Being mindful of the trappings of vocational awe, with the understanding that we can cause harm even as we are trying to provide care, is the only way to be honest about the kind of care we are providing people and the kind of harm we are doing to our patrons and each other.

The concept of carceral care is given to us by scholars and organizers of prison abolition. Abolition as a lens is an important tool to make visible the invisible ways in which our society enacts violence upon minoritized populations to maintain societal control (Davis, 2003; Kushner, 2019). With the uprisings in late spring 2020, we saw a lot of discourse regarding defunding and outright abolition of police. Regardless of how we think about abolition as individuals in the library profession, the lens of abolition allows us to see injustices and to identify care loops - that is to say, the phenomenon in which library workers criminalize our community in our attempts to serve them. Critics of abolition call it unsustainable, unrealistically optimistic or destructive to society. As abolitionist scholar Ruth Wilson Gilmore reminds us, though, abolition is not about destruction but creation, and it is through that creation that we no longer have to rely upon former models of carceral care (Kushner, 2019). In fact, it is a call and an opportunity to create the care we wish to provide. Understanding this about ourselves means that, as a location of care, we have an opportunity to lead in a care profession and to divest from forms of carceral care. Otherwise, we will continue to follow and perpetuate the carceral care loop.

\section{Special thanks to abolition at University of Illinois Chicago (UIC)}

In the summer of 2020, the Abolition at UIC collective hosted several teach-ins. Organized by graduate students, the teach-ins featured conversations and scholarship by graduate students, faculty, and organizers within our campus and city communities who strive to 
imagine a world without policing and violence against minoritized communities. While attending the teach-ins, I was able to first begin to see the ties of carceral care to my own practices of librarianship. Without the labor of the organizers and invited speakers, this article would not be possible. I am forever thankful to the Abolition at UIC community for being given the space to learn, reflect and imagine change.

\section{References}

Abolitionist Library Association (2021), "Abolitionist library association”, available at: https://modestcolden-86b261.netlify.app/ (accessed 4 July 2021).

Alexander, M. (2020), The New Jim Crow: Mass Incarceration in the Age of Colorblindness, New Press, New York, NY.

American Civil Liberties Union (no date), "School-to-prison pipeline", available at: https://www.aclu. org/issues/juvenile-justice/school-prison-pipeline/school-prison-pipeline-infographic (accessed 4 July 2021).

American Library Association (no date a), "Libraries matter: impact report", available at: https://www. ala.org/tools/research/librariesmatter/ (accessed 4 July 2021).

American Library Association (no date b), "Library fines and collection agencies", available at: https:// www.ala.org/news/mediapresscenter/presscenter/onlinemessagebook/finescollectionagencies_ tp (accessed 29 June 2021).

American Library Association (2020), ALA Condemns Police Violence, available at: https:// americanlibrariesmagazine.org/blogs/the-scoop/ala-executive-board-condemns-police-violencepeople-color-protesters-journalists/ (accessed 4 July 2021).

Balazer, C. (2020), "Rethinking police $\mathrm{P}=$ presence: libraries consider divesting from law enforcement", American Libraries Magazine, 8 July, available at: https://americanlibrariesmagazine.org/2020/ 07/08/rethinking-police-presence/ (accessed 4 July 2021).

Barnard, A. and McGinty, J.C. (2007), "How one overdue book can hurt a credit record", The New York Times, 26 December, available at: https://www.nytimes.com/2007/12/26/nyregion/26debate.html (accessed 4 July 2021).

Biddle, S. (2021), "LexisNexis to provide giant database of personal information to ICE", The Intercept, 2 April, available at: https:/theintercept.com/2021/04/02/ice-database-surveillance-lexisnexis/ (accessed 4 July 2021).

Bourne, J. (2020), “This is what a radical intervention could look like': an interview with Barbara Ransby", Race and Class, Vol. 62 No. 2, pp. 14-23, doi: 10.1177/0306396820950142.

Dahl, J. (2012), Fla. Woman Marissa Alexander Gets 20 Years for 'warning Shot': Did She Stand Her Ground?, available at: https:/www.cbsnews.com/news/fla-woman-marissa-alexander-gets-20years-for-warning-shot-did-she-stand-her-ground/ (accessed 4 July 2021).

Dapier, E. and Knox, E. (2020), "When not to call the cops", American Libraries, 8 July, available at: https://americanlibrariesmagazine.org/2020/07/08/rethinking-when-to-call-the-cops/ (accessed 4 July 2021).

Davis, A.Y. (2003), Are Prisons Obsolete?, Seven Stories Press, New York, NY.

Dudek, M. (2020), "Chicago public library says eliminating fines has paid off", Chicago Sun Times, 11 November, available at: https://chicago.suntimes.com/2020/11/11/21561316/chicago-publiclibrary-overdue-fines-eliminated-books-readers-returned (accessed 4 July 2021).

Ettarh, F. (2018), "Vocational awe and librarianship: the lies we tell ourselves", In the Library with the Lead Pipe, 10 January, available at: https:/www.inthelibrarywiththeleadpipe.org/2018/ vocational-awe/ (accessed September 14, 2021).

Fassler, E. and Ventura, A. (2021), "Police in libraries: what the cop-free library, ovement wants", Teen Vogue, 2 February, available at: https://www.teenvogue.com/story/police-public-libraries (accessed 4 July 2021). 
Freudenberger, E. (2019), "Not just narcan”, Library Journal, available at: https://www.libraryjournal. com?detailStory $=$ Not-Just-Narcan (accessed 4 July 2021).

Goble, C. (2021), "Social workers to the rescue?: an urgent call for emergency response reform", Fordham Urban Law Journal, Vol. 48 No. 4, pp. 1021-1065. available at: https://ir.lawnet. fordham.edu/ulj/vol48/iss $4 / 7$.

Heitzeg, N. (2009), "Education or incarceration: zero tolerance policies and the school to prison pipeline", Forum on Public Policy, available at: https://files.eric.ed.gov/fulltext/EJ870076.pdf (accessed 14 September 2021).

International Federation of Social Workers (2014), Global Definition of Social Sork - International Federation of Social Workers, available at: https://www.ifsw.org/what-is-social-work/globaldefinition-of-social-work/ (accessed 4 July 2021).

Jacobs, L.A., Kim, M.E., Whitfield, D.L., Gartner, R.E., Panichelli, M., Kattari, S., Downey, M.M., McQueen, S.S. and Mountz, S.E. (2020), "Defund the police: moving towards an anti-carceral social work", Journal of Progressive Human Services, Vol. 32 No. 1, pp. 37-62, doi: 10.1080/ 10428232.2020 .1852865 .

Jaeger, P.T., Gorham, U., Greene Taylor, N., Kettnich, K., Sarin, L.C. and Peterson, K.J. (2014), “Library research and what libraries actually do now: education, inclusion, social services, public spaces, digital literacy, social justice, human rights, and other community needs", The Library Quarterly, Vol. 84 No. 4, pp. 491-493, doi: 10.1086/677785.

Jane Addams Hull House Museum (no date), About Jane Addams, available at: https://www. hullhousemuseum.org/about-jane-addams (accessed 4 July 2021).

Jones, P.A., Jr. (1989), "The history and development of libraries in American higher education", College and Research Libraries News, Vol. 50 No. 7, pp. 561-564, doi: 10.5860/crln.50.7.561.

Kim, M.E. (2018), "From carceral feminism to transformative justice: women-of-color feminism and alternatives to incarceration", Journal of Ethnic and Cultural Diversity in Social Work, Vol. 27 No. 3, pp. 219-233, doi: 10.1080/15313204.2018.1474827.

Krueger, P. (2010), "It's not just a method! the epistemic and political work of young people's lifeworlds at the school-prison nexus", Race Ethnicity and Education, Vol. 13 No. 3, pp. 383-408, doi: 10.1080/13613324.2010.500846.

Kushner, R. (2019), "Is prison necessary? Ruth Wilson Gimore might change your mind”, New York Times Magazine, 17 April, available at: https://www.nytimes.com/2019/04/17/magazine/prisonabolition-ruth-wilson-gilmore.html (accessed: 26 June 2021).

Lamdan, S. (2019), "Librarianship at the crossroads of ICE surveillance", In the Library with the Lead Pipe, 13 November, available at: https://www.inthelibrarywiththeleadpipe.org/2019/icesurveillance/ (accessed 14 September 2021).

Lawson, V. (2007), "Geographies of care and responsibility”, Annals of the Association of American Geographers, Vol. 97 No. 1, pp. 1-11, doi: 10.1111/j.1467-8306.2007.00520.x.

Lewis, A.M. (2008), (Ed.) Questioning Library Neutrality: Essays from Progressive Librarian, Library Juice Press.

Meiners, E.R. (2011), "Ending the school-to-prison pipeline/building abolition futures", The Urban Review, Vol. 43 No. 4, pp. 547-565, doi: 10.1007/s11256-011-0187-9.

Nguyen, N. (2021), "Carceral care work: strengthening policing through the provision of social services”, ACME: An International Journal for Critical Geographies. (In press).

O'Hara, M.E. (2017), Bresha Meadows Case: Teen Who Killed Father Gets Deal that Spares Jail Time, NBC News, available at: https://www.nbcnews.com/news/us-news/bresha-meadows-case-teenwho-killed-father-gets-deal-spares-n762906 (accessed 4 July 2021).

Reiner, R. (2010), The Politics of the Police, 4th ed., Oxford University Press, New York, NY. 
Richie, B. (2012), Arrested Justice: Black Women, Violence, and America's Prison Nation, New York University Press, New York, NY.

Richie, B.E. and Martensen, K.M. (2020), "Resisting carcerality, embracing abolition: implications for feminist social work practice”, Affilia, Vol. 35 No. 1, pp. 12-16, doi: 10.1177/0886109919897576.

Rodríguez, D. (2010), "The disorientation of the teaching act: abolition as pedagogical position", Radical Teacher, Vol. 88 No. 1, pp. 7-19, doi: 10.1353/rdt.2010.0006.

Sabino, P. (2021), "A boys and girls club will open at controversial police academy on west side. critics say it will 'Traumatize' the kids it aims to help", Block Club Chicago, 1 June, available at: https:// blockclubchicago.org/2021/06/01/a-boys-girls-club-is-opening-at-controversial-police-academy-onwest-side-critics-say-it-will-traumatize-the-kids-it-aims-to-help/ (accessed 4 July 2021).

Schenwar, M. and Law, V. (2021), Prison by Any Other Name: the Harmful Consequences of Popular Reforms, New Press, New York, NY.

Shoenberger, E. (2020), "Librarians sound alarms about pandemic protocols", Chicago Reader, 17 December, available at: https://www.chicagoreader.com/chicago/librarians-sound-alarms-aboutpandemic-protocols/Content?oid $=85038418$ (accessed 4 July 2021).

Skiba, R.J., Arredondo, M.I. and Williams, N.T. (2014), "More than a metaphor: the contribution of exclusionary discipline to a school-to-prison pipeline", Equity and Excellence in Education, Vol. 47 No. 4, pp. 546-564, doi: 10.1080/10665684.2014.958965.

Stovall, D. (2018), "Are we ready for 'school' abolition?: thoughts and practices of radical imaginary in education”, Taboo: The Journal of Culture and Education, Vol. 17 No. 1, doi: 10.31390/taboo.17. 1.06 .

Tapia, R. (2020), What Is the Carceral State?, Community Organizations Team, available at: https:// storymaps.arcgis.com/stories/7ab5f5c3fbca46c38f0b2496bcaa5ab0 (accessed 14 September 2021).

Trudeau, D. (2008), “Towards a relational view of the shadow state", Political Geography, Vol. 27 No. 6, pp. 669-690, doi: 10.1016/j.polgeo.2008.07.002.

Wahler, E.A., Provenence, M.A., Helling, J. and Williams, M.A. (2020), "The changing role of libraries: how social workers can help", Families in Society: The Journal of Contemporary Social Services, Vol. 101 No. 1, pp. 34-43, doi: 10.1177/1044389419850707.

Wald, J. and Losen, D.J. (2003), "Defining and redirecting a school-to-prison pipeline", New Directions for Youth Development, Vol. 2003 No. 99, pp. 9-15, doi: 10.1002/yd.51.

Whalley, E. and Hackett, C. (2017), "Carceral feminisms: the abolitionist project and undoing dominant feminisms”, Contemporary Justice Review, Vol. 20 No. 4, pp. 456-473, doi: 10.1080/10282580.2017. 1383762.

Wheeler, J. (2021), "How much is not enough?': public library outreach to 'disadvantaged' communities in the war on poverty", The Library Quarterly, Vol. 91 No. 2, pp. 190-208, doi: 10.1086/713043.

Wolch, J.R. (1990), The Shadow State: Government and Voluntary Sector in Transition, Foundation Center, New York, NY.

\section{Corresponding author}

Teresa Helena Moreno can be contacted at: thrmoren@uic.edu
Libraries as locations of carceral care 